FACULDADE DE MEDICINA DA UNIVERSIDADE DE SAO PAULO

1.* CADEIRA DE CLINICA CIRURGICA - PROF. ALIPIO CORREIA NETO

\title{
O ABCESSO PÉLVICO DO FUNDO DE SACO DE DOUGLAS APÓS AS APENDICECTOMIAS
}

\author{
DR. EURYCLIDES DE JESUS ZERBINI \\ 1. Assistente e Chefe de Clínica
}

A literatura publicada sobre apendicite é muito vasta, mas ha sempre interesse no seu estudo continuo, por ser uma das afẹcções cirúrgicas mais comuns.

As complicações da apendicite, tratada ou não cirúrgicamente, constituem um capítulo muito importante da patologia abdominal. As primeiras demonstrações clínicas das apendicites foram justamente as suas complicações mais usuais - a peritonite e os abcessos intraperitoniais - que o cirurgião aprendeu a tratar, descobrinda logo depois a lesão inicial no apêndice.

Ultimamente, a incidencia das complicações da apendicite tem diminuido, e isso devemos ao habito de se operar precocemente todos os casos diagnosticados, emquanto o processo anatomopatológico está restrito ao apêndice. Mesmo assim, uma grande parte dos pacientes é obrigada a permanecer por muito tempo no hospital, e alguns vem a falecer em consequencia de uma comp̂licaçã́o.

O abcesso pélvico localisado no fundo de saco de Douglas é uma complicação muito frequente após as apendicites supuradas. Comtudo, após as apendicectomias "a frigore" é uma complicação rara, mas que deve ser conhecida, para não se fazer o diagnóstico de enterocolite aguda, por causa das evacuações disenteriformes em um apendicectomisado, que necessita uma nova intervenção para abertura de um abcesso.

$$
\text { * * * }
$$

O abcesso do fundo de saco de Douglas que aparéce como complicação das apendicites supuradas é conhecido ha muitos anos, e já em 1900 encontramos um trabalho completo de ROTTER, na Alemanha. Entretanto existem na litratura poucas obsrvações descritas desses abcessos após apendicectomias faceis e praticadas durante a fase crô- 
nica da molestia, justamente o que mais nos interessa no momento. No primeiro caso trata-se evidentemente de uma complicação da propria molestia, que apesar de uma técnica rigorósa, ou mesmo antes da operação, icausou o abcesso. No segundo caso raras vezes isso se dá, e em geral a complicação, ou é uma consequencia da técnica pela qual foi feita a apéndicectomia, ou de estados especiais do organismo que favoreçem a hemorragia intraperitonial e sua posterior infecção. Assim, é habito dividirem-se as complicações das apendicites em 2 grandes grupos: $10^{\circ}$ - complicações que séguem as apendicectomias por processos crônicos ou agúdos operados dentro das primeiras hóras ; $2 .^{\circ}$ complicações que séguem apendicectomias por apendicites agudas que datam de muitas hóras, ou que já formaram abessos. No primeiro caso culna-se a técnica pelo aparecimento da complicação; no segunclo a molestia, apesar de uma técnica corréta. Naturalmente nem todns os casos pódem ser encaixados tão sumariamente dentro desta classificação, porque as complicações e a evolução diferente em operados $\mathrm{cm}$ o mesmo numero de hóras, depende muito da especie e principalmente da virulencia dos germens em questão.

Podemos então distinguir muito bem os abcessos apendiculares aparecidos como consequencia de uma apendicite aguda supurada e num segundo grupo, os abcessos apendiculares que aparecem inesperadamente, como.complicação de uma apendicite simples.

No primeiro caso póde-se separar o chamado abcesso periapendicular, do abcesso formado á distancia.

A formação de um abcesso apendicular no curso de uma apendicito a cula supurada é um exemplo típico de abcesso peritonial consequente a uma peritonite localisada. Sempre que um orgão qualquer recobitu pela cerosa peritonial é séde de um processo inflamatorio, do o peritonio que envolve essa região inflamada torna-se hiperêmico até uma distancia respeitavel do fóco de infecção. Forma-se então um exsudato rico em elementos leucocitarios oriundos dos vasos e rico tambem em fibrina, que promove a aderencia com as superficies peritoniais visinhas em semelhante estado de reação. Esta reação peritonial constitue uma defesa do organismo, e se estende até uma região bem afastada do orgão infetado. Com o tempo, as aderencias vãcse organisando e formam uma parede para o abcesso, que aumenta graças á lise produzida pelos germens; ao mesmo tempo, a porção peritonial que está afastada da parede do abcesso que se formou, volta aos poucos ao seu estado normal, porque não necessita permanecer em estado de defesa, uma vez que o abcesso está septado. Por esse mecanismo simples e conhecido ha muito, forma-se um abcesso no curso de uma apendicite aguda. Mas este abceso é periapendicular e o apendice continua a manter relações com ele.

Existem outros abcessos que tambem são consequencia da apendicite aguda, mas que se formam á distancia da infecção apendicular primaria, por uma migração dessa mesma infecção; dentre eles os mais comuns são os abcessos subfrênicos e os abcessos pélvicos localicados 
principalmente no fundo de saco de Douglas. Estes abcéssos secundarios e á distancia apresentam um grande papél entre as complicações. da apendicite supurada, pois eles pódem coexistir com a lesão original do apêndice e mascarar completamente a sua existencia, sendo tomados como abcessos primarios; ou eles pódem aparecer no curso do tratamento, ou muito tempo após a lesão inicial, requerendo nova operação.

Os abcessos pélvicos, mas particularmente os abcesşos do fundo de saco rétovesical no homem e do fundo de saco rétovaginal de Douglas na mulher ocupam o primeiro lngar entre os abcessos secundarios á distancia. Isto acontéce com grande frequencia após os processos apendiculares, pela maior visinhança; entretanto qualquer estado. mórbido capaz de produzir um exsudato infaratório intraperitoniai póde dar origem a um abcesso secundario do Dougiau, porque no decubito supino, e mesmo no dorsal, todos os liquidos intraperitoniais tem tendencia para drenar para, a pelve, e nela para o fundo de saco, que é o ponto de maior dclive. Na fig. n. $^{\circ} 1$, observamos que o espaço parietocólico e mesentériocólico direitos, drenam para a fóssa iliaca direita, e esta drena para a pequena bacia; o espaço mesentériocólico esquerdo drena dirétamente para a pequena bacia e o pariétocólicơ esquerdo drena para a fóssa iliaca esquerda e daí para a pequena bacia.

Foi baseado nestes conhecimentos que o cirurgião americano FOWLER propoz que se colocasse os pacientes em posição sentada no leito, para favorecer a descida dos exsudatos inflamatórios para: o Douglas durante o tratamento das peritonites pois acreditava que nessa região, a absorção dos produtos tóxicos pelo peritonio era menor do que em outras partes da cavidade. Naturalmente, nem sempre essa drenagem se faz assini tão simplesmente, pois as alças intestinais distendidas, dificultam a translação dos exsudatos, favorecendo o recmento dos abcessos secundarios, entre as proprias alças,

- O conhecimento destes fatos explica porque uma grande parte de cirurgióes drena a pequena bacia e se possivel o Douglas nos casos de apendicites francamente supuradas. Essa técnica é razoavel; entretanto a drenagem é sempre incompléta porque deve agir por sifonagem, e além disso o dreno é isolado por fibrina em algumas hóras, permitindo a formação de um abcesso pélvico apesar da drenagem.

Num segundo grupo, encontramos os abcessos do Douglas que aparécem no pósoperatório de uma apendicite operada corrétamente e "a frigore". A estes casos chamamos particularmente a atenção, pois trata-se de uma complicação não muito rara, e que frequentemente é rotulada entre os clínicos como um recrudecimento de uma vélha co. lite que, ás vezes, nunca existiu.

Estudando a causa dos abcessos intraperitoniais após intervenções aséticas sobre o apêndice, CHUTRO enuméra as seguintes: $10^{\circ}-o$ liquido de reação que banha o apêndice que já está contaminado (forma rara) $; 2 .^{\circ}$ - o material que sai do côto apendicular e contamina o 
peritonio $33^{\circ}$ - a manipulação do côto quando se tem o mau costume de fazer o sepultamento após secionar o apêndice; $4 .^{\circ}$ - o côto apendicular é tão longo que o seu esfacelo é capaz de produzir um abcesso, muitas vezes pútrido; $5^{\circ}$ - desinvaginação do côto por falta de sepultamento; 6.0 - purgantes que forçam o sepultamento; $7 .^{\circ}$ - abandono do côtọ não bem esterelisado, sem invaginar; $80^{\circ}$ - frequentemente o cirurgião deixa uma parte do méso fixo na base do apêndice: a interposição de tecido gorduroso dificulta a cicatrisação séroserósa, e o côto, em via de esfacelo, contamina com o seu conteudo, o tecido gorduroso do meso envaginado, que de si não tem poder de defesa e origina-se um flegmão profundo; $9 .^{\circ}$ - um ganglio inf ctado póde supurar.

Forma-se assim um abcesso paracecal, que se ramifica entre as alças intestinais da maneira mais caprichosa até alcançar o Douglas.

Pessoalmente, acreditamos que ha a possibilidade de se formar um abcesso no Douglas após uma apendicectomia simples, sem que antes se forme um abcesso paracecal. De fato, nos parientes portadores do abcesso pélvico do Douglas após a apendicectomia, muitas vezes nada se observa pelo exame físico da fóssa iliaca direita, encontrando-se um processo isolado na pequena bacia. Por outro lado o simples fato de permanecer na cavidade peritonial o côto do apêndice com um sepultamento defeituoso, ou mesmo sem sepultamento, não é suficiente para explicar a formação de um abcesso, poris foi demonstrado experimentalmente por GRAVITZ e MEYER que dessa maneira o peritonio póde exercer sua ação bactericida mais facilmente do que se o côto vier a contaminar os tecidos subperitoniais do céco após o sepultamənto. Além disso clínicamente obsenva-se no Serviço do Prof. A lipio Correia Neto, em que nunca se faz o sepultamento, um bom pósoperatório.

Após observarmos que os abcessos do Douglas abertos via retal precócemente apresentavam uma grande quantidade de sangue, procuramos explicar a patogenia do abcesso pela hemorragia.

A hemorragia após uma apendicectomia póde ser primaria, originando-se do mésoapêndice mal ligado, ou de uma aderencia vascularisada: a artéria apendicular emite um ramo para o fundo do céco e base do apêndice, que nem sempre é incluido na ligadura, e póde permanecer secionado e não ligado. Outras vezes a hemorragia é tardia. Para a explicação desta hemorragia secundaria não existe uma hipótese que satisfaça integralmente ao espírito. Póde-se admitir, que o côto apendicular não sepultado e mal desinf-tado produza uma infecção do côto do mésoapêndice em sua parte distal á ligadura da artéria, pois essa parte entra em necróse anêmica e o tecido perde complétamente sua defesa própria, transformando-se em um ótimo meio de cultura. Assim necrosado e infetado, o côto do meso se desprende precócemente permitindo uma hemorragia arterial. Esta explicação não satisfaz sempre pois paréce natural que uma vez ligada. a artéria se obstrua definitivamente pela formaçăo de um trombo. Em todo caso, 
a hemorragia existe e o sangue infetado pelo côto apendicular não sepultado vem se coletar no fundo de saco de Douglas, onde os germens, após curta encubação, fazem supurar a coleção de sangue. Normalmente o sangue dentro do peritonio é absorvido muito rapidamente, como acontece com as soluções isotônicas. Entretanto quando existe uma solução de continuidade do peritonio, o sangue sempre se coagula, e então, a formação da fibrina provóca uma exsudação tanto intraperitonial como no tecido subperitonial. A absorção compléta do coagulo formado exige mezes. Se o sangue existente no peritonin é infetado, então a absorção é nula e o sangue retirado não tarda em supurar, pois é bom meio de cultura. Os signais gerais produzidos pela peritonite localisada ou generalisada não são devidos a uma absorção do material infetado existente dentro do peritonio mas sim do exsudato que se forma no tecido subperitonial."

De qualquer maneira, o hemoperitonio infetado, ou o exsudato inflamatório chegado ao Douglas, dão origem a uma pelvio-peritonite, com edema inflamatório invadindo a visinhança. $\mathrm{E}$ o chamado infiltrado do Douglas. Esse exsudato enche o Douglas, e aumenta progressivamente, elevando as alças intestinais que são acoladas umas ás outras pela fibrina, que faz aderir tambem essas alças á parede abdominal; isso localisa o processo inflamatório. Se a reação do peritonio é grande e a virulencia do germen pequena, tudo póde involuir dentro de pouco tempo. Mas em geral o exsudato vai á formação de pús e estabelece-se o abcesso do Douglas, que aumenta rapidamente de tamanho, produzindo sinais de compressão do réto, da bexiga, e em alguns casos raros, tornando-se saliente na parede anterior do abdomen, por sobre o pubis.

Com o evoluir, o abcesso procura uma drenagem natural seja no réto, o que é mais comum, seja na bexiga. Em alguns casos, o ponto de thenor resistencia é justamente a parede superior do abcesso, formada pelo acolamento das alças intestinais. Nesse caso, o pús é derramado na cavidade peritonial que se encontra completamente livre. pois como já dissemos, o peritonio, nas proximidades da infecção, sofre um processo de reação que é a sua defesa durante o bloqueio dessa infecção. Desde que ela seja septada, o peritonio adjacente volta ao estado normal, porque não ha necessidade desse estado de réação. O resultado disso é uma peritonite generalisada de consequencias graves. O mesmo acontece quando o abcesso é aberto cirurgicamente por via transperitonial, o que deve ser classificado como um gravissimo erro.

\section{SINTOMATOLOGIA}

O ponto mais importante deste trabalho é chamar a atenção para a sintomatologia dos abcessos do Douglas; em geral ela é muito caraterística e o diagnóstico póde ser feito com 2 ou 3 sintomas. Isso apresenta um grande interesse para o clínico. 
Quando o paciente foi operado por uma apendicite supurada, os sinais de abcesso pélvica pódem aparecer pouco depois da intervenção, ou o paciente procura o cirurgião já com esses sinais.

Quando o paciente foi operado fóra da crise aguda, os sinais de abcesso pélvico aparecem geralmente no $5^{\circ}$ dia do pós-operatório.

O sintoma mais evidente é a evacuação disenteriforme, que consiste em fézes líquidas, em geral acompanhadas de razoavel quantidade de catarro, ás vezes sanguinolento. As evacuações frequentes e líquidas são sempre dolorósas e o tenesmo é uma queixa que nunca falta. A causa desses incomodos é o edema da mucósa retal, que se acha nas visinhanças do abcesso. Esse edema póde ser verificado pela retoscopia, observando-se a mucósa muito infiltrada, e recoberta por uma camada espessa de muco; trata-se de uma verdadeira retite da. parede anterior do réto. Este sinal é tão importante e frequente, que se póde dizer que a ocurrencia de evacuações disenteriformes, ou seja diarréa com catarro, no pósoperatório de uma apendicectomia, equivale a abcesso do Douglas, até que se próve o contrario. A observação desse quadro leva o clínico a um exame de fézes negativo e é resistente aos tratamentos usuais das disenterias.

Estes sinais coincidem cọm a elevação da temperatura, que inicia uma curva de supuração com remissões matutinas. Outros sinais de repercussão orgânica são comuns, como o estado de astenia intensa e mesmo nauzeas e vômitos, que mostram a intoxicação.

Desde que a atenção tenha sido chamada para o réto, deve-se proceder imediatamente a um exame protológico.

Um dos sinais mais importantes é a paralisia dos esfincteres de fechamento do anus. Com o tóque digital percebe-se que os eśfincteres estão relaxados, deixando penetrar o dedo com facilidade e senı provocar dôres, o que o prático distingue imediatamente por comparação com um tóque normal. Nos casos muito avançados o relaxamento esfincteriano vai a tal ponto que o anus permanéce aberto, deixando vêr a mucósa que recóbre a ampola retal, infiltrada e recoberta por uma verdadeira geléa. Póde-se então introduzir 2 ou 3 dedos no réto e mesmo um espéculo, sem que o paciente demonstre dôr. Esta paralisia existe nos dois esfincteres interno e esterno, que perdem a sua tonicidade, embóra o esfincter esterno conserve a sua motilidade voluntaria, não sendo muito comuns os casos de incontinencia de fézes

A causa dessa paralisia esfincteriana tem sido muito discutida pelos autores, podendo-se distinguir 3 opiniões: 1 - compressão dos nervos pelo abcesso: 2 - ação tóxica dos produtos bacterianos: 3 edema e tumor retal.

LÄWEN em 1921 chamou a atenção para o fato de que o tumor não age diretamente sobre o aparelho esfincteriano, porque está situado muito acima dele. Daí pensar-se que poderia agir sobre os trajétos nervosos que, passando proximos ao abcesso, vêm ter aos enfincteres. $O$ esfincter externo recebe uma inervação voluntaria do 
sistema cerebro-espinal, atravéz dos nervos pudendos e hemorroidarios inferiores. Estes não são lesados pelo abcesso, tanto que uma contração voluntaria do esfincter é possivel. Além disso ambos os esfincteres recebem uma inervação simpática, oriunda dos plexos mesentérico inferior e hipogástrico, e parasimpática, oriunda do plexo hemorroidario médio atravéz do nervo pélvico. O simpático exerce uma ação depressôra e o parasimpático estimuląnte sobre o tonus dos esfincteres ànais, de maneira que o seu relaxamento póde-se originar de uma paralisia do parasimpático ou excitação do simpático. Admite-se que os processos do fundo de saco de Douglas que exercem uma pressão sobre os nervos, sejam capazes de provocar esses refléxos. Entretanto, a pressão deve ser muito exagerada pois o relaxamento esfincteriano observa-se durante o parto, mas não se observa em casos de retroversão ou tumores do utero que exercem uma compressão menos exagerada.

Considerando que a compressão exercida pelo abcesso sobre os trajétos nervosos nunca é tão grande nos casos de abcessos do Douglas, L ̈̈WEN passou a admitir que a ação prejudicial sobre os trajétos nervosos era exercida pelas toxinas bacterianas que agiam local. mente sobre os tecidos. Embóra não se póssa negar categóricamente esta ação tóxica sobre o sistema nervoso, o fato é que não existem provas evidentes dessa hipótese.

Outros autores chamaram a atenção para o fato de que o rclaxamento dos esfincteres póde ser consequencia de uma frequente e inutil necessidade de esvasiamento do réto. Em geral existe um enchimento da empola retal produzido não só pelo abaulamento formado pelo abcesso, mas tambem pelo edema das paredes retais que se estende para cima e para baixo do sitio da inflamação. Tudo se passa como se a empola retal estivesse permanentemente cheia por um bolo fecal, que nunca fosse eliminado.

A mais simples explicação do relaxamento dos esfincteres anais. parece ser a seguinte. Normalmente os esfincteres se relaxam durante a evacuação mediante um mecanismo reflexo, cujo ponto de partida é a irritação da mucosa retal pelo bolo fecal. Quando existe uma irritação muito grande e anormal da mucosa retal, como acontece por exemplo no cancer ulcerado do réto, nas retites, no abcesso do Douglas acompanhado de edema das paredes do réto inclusive da mucósa, então persiste sempre uma vontade imperiosa de evacuar, embora a empola esteja vasia. Porisso, reflexicamente, os esfincteres permanecem relaxados.

Naturalmente estas hipóteses não estão em contradição, e é possivel que todos os fatores corroborem para o mesmo fim. Entretanto, devemos lembrar que nos casos de coleções liquidas do Douglas sem infecção, como acontece nas hemorragias intracavitárias, pódə-se observar o relaxamento esfinteriano, embora isso não seja obrigatório. Paréce portanto que a intoxicação bacteriana não é essencial para $\alpha$ 
relaxamento dos esfincteres. Frequentemente a paralisia esfincteriana acompanha tambem os tumores do réto, e particularmente os car. cinomas e tambem nesses casos fica-se indeciso em admitir se a paralisia é consequencia da compressão dos trajétos nervósos que passam juntos ao tumor ou se consequncia do enchimento da empola retal.

Observada a paralisia dos esfincteres no inicio do tóque retal, terminamos a introdução do dedo no réto e fazemos uma palpação ligeira de todas as suas paredes. Em seguida detemos o nosso dedo na parede anterior, onde encontramos a prostata do homem, ou o colo do utero na mulher, ótimos pontos de reparo. É acima desses reparos, que está o fundo de saco de Douglas, onde devemos procurar a existencia da coleção. (Ponto de Rotter) Se se trata de um processo recente, o que existe é o chamado infiltrado do Douglas, difuso e que se distingue facilmente da prostata, porque esta apresenta contornos mais nítidos, é menór, e não é dolorósa. Se fizermos tóques repetidos no mesmo paciente, vamos observar que o infiltrado do Douglas póde seguir 2 caminhos diferentes: ou vai-se tornando cada vez menos perceptivel até desaparecer complétamente, o que coincide com a me1horia dos outros sintomas; ou então ele se localisa cada vez mais e aos poucos vai amolecendo até a formação de um abcesso. Não é certo dizer-se que o abcesso do Douglas flutua, a menos que a flutuação seja percebida entre o dedo do réto e a mão colocada na parede anterior do abdomen, o que só é possivel para enórmes coleções. A flutuação não póde ser sentida por um só dedo introduzido no réto. se reduz, e maior quando o abcesso se abre espontan amente no réto.

A importancia do tóque retal para o diagnóstico dos conteudos patológicos do Douglas, tem sido mostrada na literatura desde KULENKAMPFF, que chamava a atenção para o tóque nas úlceras gastroduodenais perfuradas, em que o conteudo gástrico tornava o Donglas doloroso; GRASSMANN em 1923 mostrou a sua importancia nas lesões traumáticas do abdomen para a pesquisa de sangue e todos cirurgiões pesquisam a resistencia dolorósa do Douglas nas apendicites agudas. Pelo tóque retal podemos sentir tambem um tumor do sigmoide que veio localisar-se no Douglas; nesse caso o tumor deixa de ser palpado na posição genupeitoral, o que não acontece com o abcesso.

Em alguns casos mais raros, após alguns dias de disenteria, aparece a obstrução intestinal mais ou menos rebelde, e um exame radiológico póde mostrar tratar-se de uma compressão das paredes do réto produzida pelo conteudo do Douglas.

As mesmas perturbações produzidas no trânsito intestinal existem tambem para o trânsito urinario e para o aparelho genital. Assim é que a dificuldade de micção e mesmo a retenção compléta de urina não são raras. As çausas desse fenomeno, são as mesmas evocadas para o réto; ou se trata de uma compressão diréta do colo da bexiga pelo abcesso, ou de lesões dos trajétos nervosos destinados á bexiga. KHAUTZ publicou um caso de anuria por compressão dos 2 uretéres por um enorme abcesso pélvico. 
As perturbações urinarias pódem tambem ser representadas pelas micções frequentes e dolorósas que traduzem uma cistite. Outras vezes póde haver uma paralisia do esfincter do colo da bexiga com incontinencia de urina.

Para o lado do aparelho genital póde haver uma vaso constrição e contração da musculatura lisa do deferente e das vesiculas seminais por excitação do plexo hipogástrico, ou pelo contrario, vaso dilatação e ereção por excitação do parasimpático. Nas mulheres, é muito comum o aparecimento de corrimento vaginal com muco e esse fato tem a mesma causa da disenteria, isto é, o edema inflamatório da mucósa. vaginal.

A palpação do abdomen é muito diferente conforme o tamanho do abcesso. Em geral ha dôr e defesa muscular em todo o abdomen inferior, particularmente no hipogástrio. Naturalmente se o abcesso cresce muito, passa a ser palpado por sobre o pubis ou em uma das fóssas iliacas.

Quanto aos exames de làboratório, póde-se lançar mão de uma contagem global e específica que revelará um desvio para esquerda, com o quadro de processo inflamatório recente. Uma radiografia com contraste póde demonstrar a compressão do réto.

No diagnóstico diferencial, apenas vamos chamar a atenção para o grande erro de se admitir a existencia de uma colite aguda pela ocurrencia de fézes disenteriformes.

Quando se trata de uma apendicectomia feita por apendicite supurada, o aparecimento do quadro clínico descrito léva o cirurgião a pensar na possibilidade da existencia de um abcesso intraperitonial, uma vez que durante a operação já existia pús no peritonio.

Entretanto, quando a cirurgião operou o paciente fóra de crises agudas, e a operação decorreu corrétamente, repugna pensar em um abcesso, e então surge o erro comunissimo de se admitir o recrudescimento de uma colite amebiana que o paciente teve ou não. A primeira idéa é pedir cultura das fézes e se por acaso aparecem cístos amébicos, que não são patogênicos enquanto encistados, confirma-se erradamente o diagnóstico de colite. Inicia-se um tratamento antidisentérico e a surpresa do cirurgião é grande quanto o quadro clínico não se reduz, e maior quando o abcesso se abre expontaneamente no réto. dando saída a uma enorme quantidade de pús.

\section{COMPLICAÇOES}

Estabelecido o diagnóstico de abcesso do Douglas o cirurgião déve aguardar a oportunidade para um tratamento cirúrgico e emprega-lo quando esteja indicado. Se isso não se dá, o tumor vai aumentando progressivamente de tamanho e o poder citolítico das bactérias vai aos poucos destruindo as paredes do abcesso, até encontrar um ponto de saída para o pús. Essa drenagem do pús póde-se fazer no réto, na vagina, na bexiga ou na cavidade peritonial livre. 
Se a abertura do abcesso se faz para dentro do réto, e é isso que acontece numa imensa maioria de casos, o paciente elimina inesperadamente uma grande quantidade de pús com a sua diarréa, pús sanguinolento e fétido; imediatamente a fébre desaparece, o estado geral melhóra, e nos dias subsequentes a eliminação de diarréa purulenta diminue sensivelmente até sobrevir a cura espontanea do abcesso.

Se a abertura do abcesso se faz pela vagina, e esta ocurrencia é tambem relativamente frequente, o corrimento vaginal transforma-se de catarral em francamente purulento e a cura natural segue-se como para a abertura pelo réto.

A abertura do abcesso pélvico na bexiga não é tão comum como as outrás duas eventualidades. Entretanto, na literatura existem muitos casos descritos e nós mesmos temos a oportunidade de reproduzir a obs. 3, cedida gentilmente pelo nosso amigo Dr. Luiz Iervolino. Quando a celulite produzida pelo abcesso invade a parede posterior da bexiga, ha a possibilidade de sua necróse e perfuração, com aparecimento de uma piuria. Em geral este acidente é seguido tambem pela cura do paciente, e a unica terapêutica necessaria são os antiséticos urinarios. Em outros casos, essa fistula vesical póde-se fechar e desaparecer o pús na urina; semanas ou mezes após, quando a cavidade do abcesso novamente se distende, ha um recrudescimento dos sintomas e nova evacuação do exsudato purulento na bexiga. A consequencia é um estado de intoxicação crônica do paciente até que se faça uma drenagem cirúrgica eficiente do abcesso.

A complicação mais grave do abcesso do Douglas é a sua abertu.ra espontanea ou cirúrgica na cavidade peritonial livre. Em quasi todos os casos sobrevem a morte por peritonite. Os sintomas de intoxicação geral dominam o quadro clínico, principalmente quando a infecção é muito virulenta. Nenhuma terapêutica salva o paciente. Como já expusémos atraz, o peritonio das visinhanças do abcesso já esteve em um estado de reação durante a formação do abcesso, e então possuía capacidade de defesa própria, capaz de impedir a formação de uma peritonite generalisada. Entretanto, desde que o abcesso tornouse cercado por uma parede de resistencia, não ha mais necessidade desse estado de defesa permanente e desaparece a reação peritonial á distancia, voltando a seróra á disposição normal. É nesse estado que ela vai receber o pús virulento, na ocasião da rotura do abcesso; a peritonite generalisada é quasi inevitavel.

Em casos muito raros de abcessos pélvicos, é possivel que as barreiras naturais oferecidas pelas "fascias" e pelo musculo elevadôr do anus não consigam oferecer resistencia ao pús, sendo invadidos e a infecção alcança a fóssa inquio-retal abrindo-se na péle do perineo, como: uma fistula paraanal.

\section{TRATAMENTO}

O tratamento do abcesso do Douglas é essencialmente cirúrgico

e consiste na sua drenagem. Entretanto a operação não deve ser in- 
dicada precocemente mas o operadôr deve ter muita paciençia e esperar alguns dias, para que o pús se forme completamente e o diagnóstico de abcesso não adm ta contestação. Nos casos em que desconfiamos da presença de um conteudo anormal do Douglas, mas não temos certeza de se tratar de um abcesso, podemos instituir um tratamento conservador que consiste em lavagens ou clisteres de líquidos bem aquecidos, que aca ${ }^{1}$ mam as dôres e favorecem a evolução do processo. Mas, quando o tóque retal mostra nitidamente a existencia de um tumor, então deve-se fazer uma punção exploradora. Se o conteudo do Douglas é. sangue, ou um exsudato que o exame bacteriológico revela estéril ou pouco contaminado, devemos insistir no tratamento conservadôr por mais alguns dias, observando o estado geral do paciente e a curva da temperatura. Muitas vizes os processos regridem, e salvamos o paciente dos inconvenientes de uma segunda operação. Entretanto, quando o material retirado pela punção é francamente purulento, a drenagem ectá indicada, pois a espéra favorece o aparecimento das complicaçõeś e a operação não salva um moribundo. Op^rar com a existenc'a da um excudato é nerigoso, pois póde não ter havido limitação e vamos contaminar a cavidade peritonial; esperar para operar um abcesso muito grande não é razoavel porque ele póde septar-se em varias lojas.

Tendo-se indicado a drenagem, devemos escolher a via de acesso ao pús. Lógicamente, a operação de escolha é uma prototomia para os homns e creanças, e uma colpotomia posterior para as mulheres. De`de 30 ou 40 anos é uso abrir॰m-se os abcessos do Douglas por uma-incisão da parede anterior do réto, procurando facilitar a ação da natureza, pois é por aí que o abcesso em geral se abre nas curas espontaneas. Nas mulheres, escolhe-se a via vaginal por ser mais simp ${ }^{1}$ c e tambem porque a vagina não é tão infetada quanto o réto. Os defensores da via retal estão em maioria. PETITCLERC tem 42 casos drenados por essa via. Outros consid ${ }^{\circ}$ ram a operação como céóa e p^rigósa, e admitem 3 grandes inconvenientes: abertura de uma alça do delgado, hemorragia pelos ramos da artéria hemorroidaria superior e abertura da bexiga com fistula vésicoretal. $O$ perigo da lesão de uma alça do delgado alojada no Douglas existe, de fato, mas póde ser sanado esp rando-se que o abcesso evolua bem, com o que espontaneamente ela será elevada. A hemorragia é evitada com uma incisão feita na linha mediana, onde não existem vasos de grande importancia. A lesão da bexiga é evitada com o uso da sondagem uretral sistemática na mesa de operações. MC GREGOR ê contrario á drenagem retal, porque $\mathrm{cm} 10$ casos perdeu 3 . Num deles havia erro de diagnóstico, pois o paciente apresentava um cisto dermoide; num segundo o autor abriu uma alça no delgado; e o terceiro apresentava outras lesões além do abcesso do Douglas. Para evitar a lesão do digado recomenda que se verifique sempre o transito do intestino delgado ao R. X. 
As drenagens propostas pela fossa isquio-retal e pela via parasagrada, apenas apresentam um valor histórico.

A via suprapúbica preferida por BLAKE (1928) apresenta as desvantagens de ser de técnica mais dificil pois necessariamente a drenagem deverá ser extraperitonial, e além disso não drena o abcesso no ponto de maior declive, mas por sifonagem.

Escolhida a via retal nunca esquecer: $1 .^{\circ}$ - não operar em duvida pois não se trata de uma operação exploradôra; $2 .^{\circ}$ - nunca deixar de esvasiar a bexiga na mesa de operações; $3 .^{\circ}$ - não operar nem precócemente, nem tardiamente; $4 .^{\circ}$ - drenar sempre na linha mediana.

Se por acaso fazemos uma laparotomia por falta de diagnóstico e durante a operação reconhecemos o abcesso, não devemos insistir, pois corremos o risco de abri-lo na cavidade livre; o corréto é suturar-se o abdomen e depois drenar o Douglas pelo réto.

Todos nossos casos foram drenados pelo réto.

\section{TÉCNICA OPERATÓRIA}

A primeira providencia é sondar a bexiga.

Nos casos muito adiantados póde-se operar mesmo sem anestesia, pois o anus está dilatado e o abcesso muito grande está nas suas proximidades. Nos outros casos deve-se fazer uma narcóse, pois a operação é muito rapida não havendo os inconvenientes da intoxicação. A anestesia local póde ser feita com cautela, evitando-se grandes infiltrações, pois o edema inflamatório constitue uma contraindicação para a anestesia local por largas infiltrações, que difundem a infecção.

Após a excitação, colocamos o paciente em posição ginecológica com a mesa de operações bem elevada. Póde-se tambem empregar a posição genupeitoral, quando não se usa anestesia geral; além de incomoda não dá boa visão, pois o abcesso, repuxado para o abdomen, deixa de fazer saliencia no réto.

Procede-se então a uma dilatação progressiva do anus com os dedos, introduzindo-se então o anuscópio de Pitanga Santos (fig. 3); observamos perfeitamente as alterações da mucosa retal e tambem o abaulamento produzido pelo abcesso. Faz-se então a punção do abcesso na linha mediana confirmando or diagnóstico já estabelecido. Tomando-se uma préga da mucósa retal, na linha mediana, praticamos com um bisturí longo a sua secção longitudinal e na linha mediana, observando-se a hemorragia (fig. 4). Com auxilio de um clamp curvo dilatamos o orificio feito, expondo a musculatura do réto sobre o abcesso. Sómente então com auxilio da mesma pinça ou do bisturí praticamos: a abertura do abcesso, dando saida ao pús (fig. 5).

$\mathrm{O}$ orificio praticado deve ser alargado e um dreno introduzido no abcesso (fig. 6). Esse dreno deve ser fixado á péle que circunda o. orificio anal, por um ponto de crina ou seda (fig. 7). 
Acidentes durante a operação:

a) Hemorragia: A parede anterior do réto na altura do fundo de saco de Douglas é irrigada pelos ramos da artéria hemorroidaria superior que alcançam o réto lateralmente, unindo-se pelas suas terminações na linha mediana. A maneira mais facil de não se lesar ramos importantes mas unicamente os ramos de pequeno calibre, é não fugir da linha mediana. Nunca observamos hemorragia talvez por obedecermos sempre este preceito. Caso exista hemorragia, parece-nos não ser tão dificil ligar a artéria que sangra, póis o anus está dilatado e temos visão ampla sobre o campo operatório.

b) Lesão da bexiga: Nunca foi publicado um caso de abertura ampla da bexiga. Geralmente o cirurgião lésa a bexiga durante a punção exploradora e em logar de pús aspira a urina. Isso aconteceu em um dos nossos casos, mas as consequencias não se fizeram sentir. Parece-nos que a fistula vésicoretal, tão temida, só aparece em casos de lesões durante a operação, com larga abertura da parede vesical. Entretanto ROEDELIUS publicou 2 casos de lesões da bexiga durante a punção e concomitante lesão de uma alça do delgado, com formação de fistulas vésicointestinais, e grave infecção urinaria; em um dos casos havia fézes na bexiga, e curou-se con um anus iliaco sigmoidiano. Naturalmente ROEDELIUS usou um trocater para a punção.

c) Lesões de alças do intestino delgado: Esse perigo existe realmente, e na literatura encontram-se alguns casos publicados. A existencia de uma alça ho Douglas póde ocorrer quando o abcesso está ainda em vias de formação ou póde ser que a alça fique presa no Douglas. Quando o cirurgião desconfia dessa ocurrencia deve verificar com um transito intestinal ao R. X. a situação das alças. Em caso de perfuração do delgado a terapêutica mais racional é a espectativa, pois querer suturar essa alça por via abdominal é um absurdo, porque vamos abrir o abcesso em peritonio livre, e tambem porque não conseguimos suturar o orificio da alça, que apresenta paredes muito friaveis devido á infecção. O acidente é muito raro.

$$
\text { * * * }
$$

A drenagem do abcesso do Douglas em mulheres adultas e não virgens, faz-se pela colpotomia posterior, cuja técnica é muito bem conhecida de qualquer genicologista.

\section{EVOLUÇÃO}

Geralmente podemos retirar o dreno após 2 ou 3 dias, quando ele não foi eliminado espontaneamente durante uma vacuação. No dia seguinte da retirada do dreno fazemos um tóque retal; e se encontramos a parede anterior do réto abaulada, dilatamos o orificio deixado pelo dreno com o próprio dedo, ou com um clamp; assim daremos saida a um exsudato que enche a loja deixada pelo abcesso. 


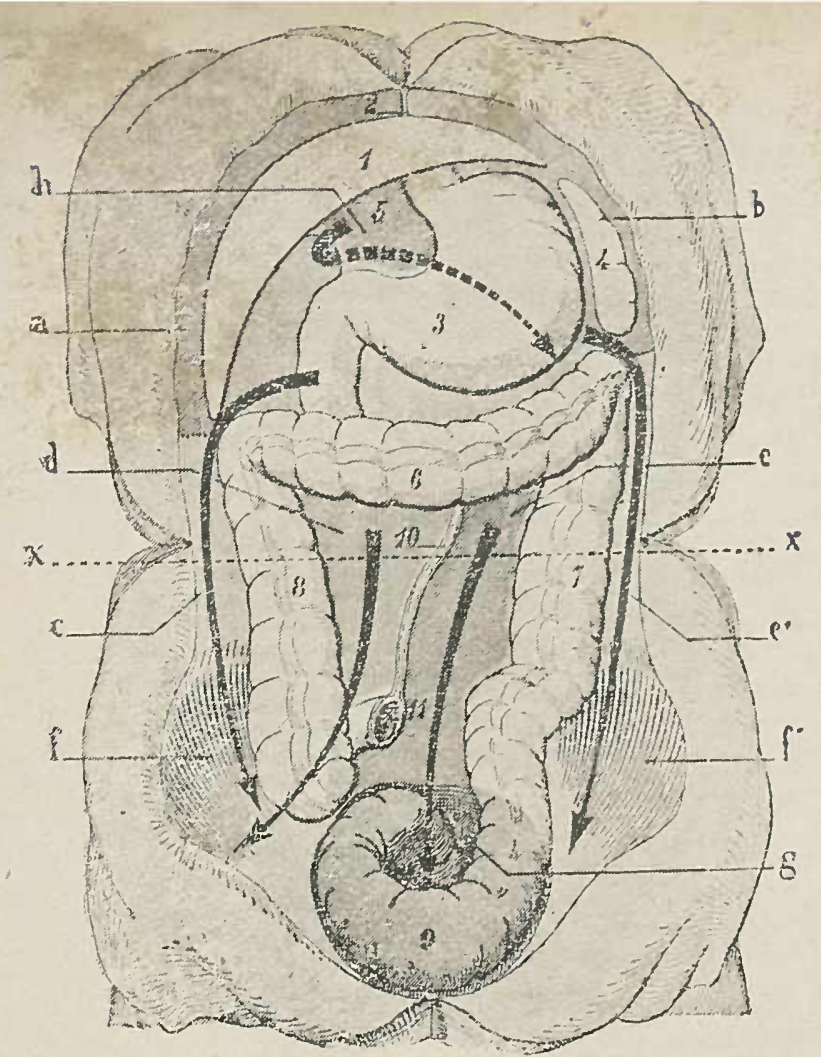

FIG. 1

Vias de drenagen dos diversos espaços da cavidade peritonial ('Testut).

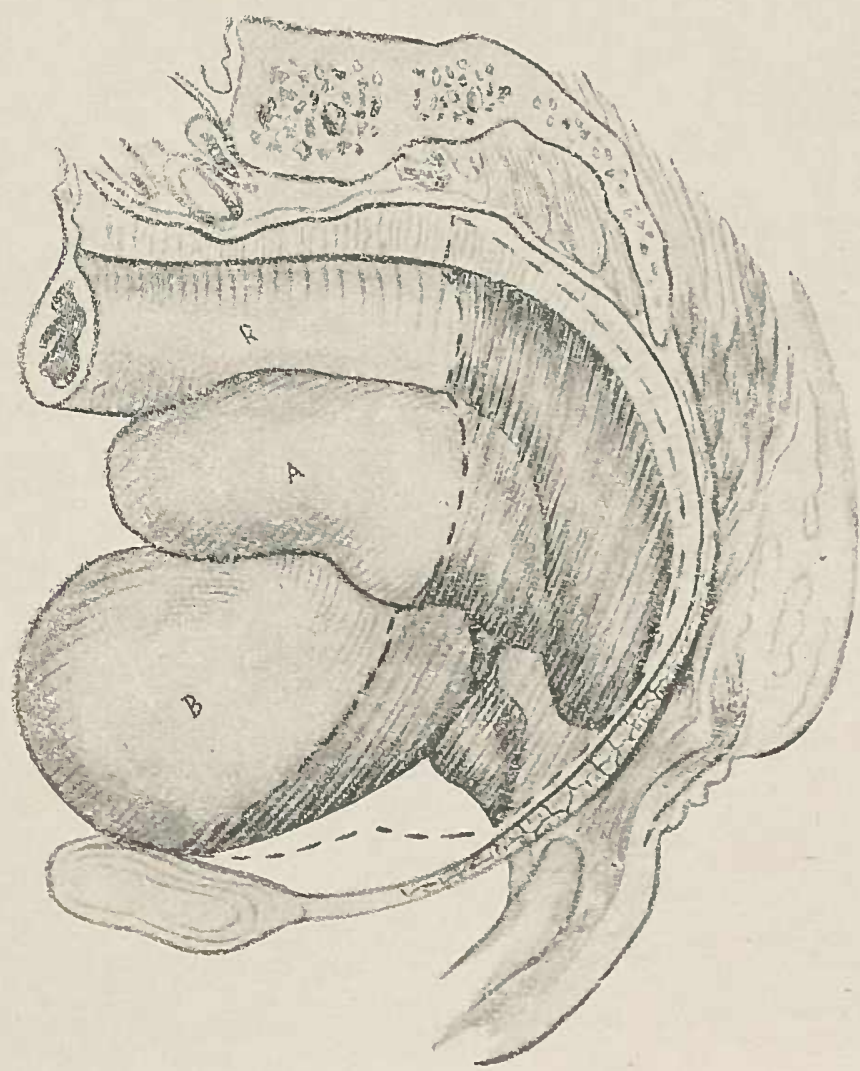

FIG. 2

Alcesso dio fundo de saco de Douglas (A) completamente formado, Alcesso do funcio de saco para frente (B) e o réto para traz $(R)$. 


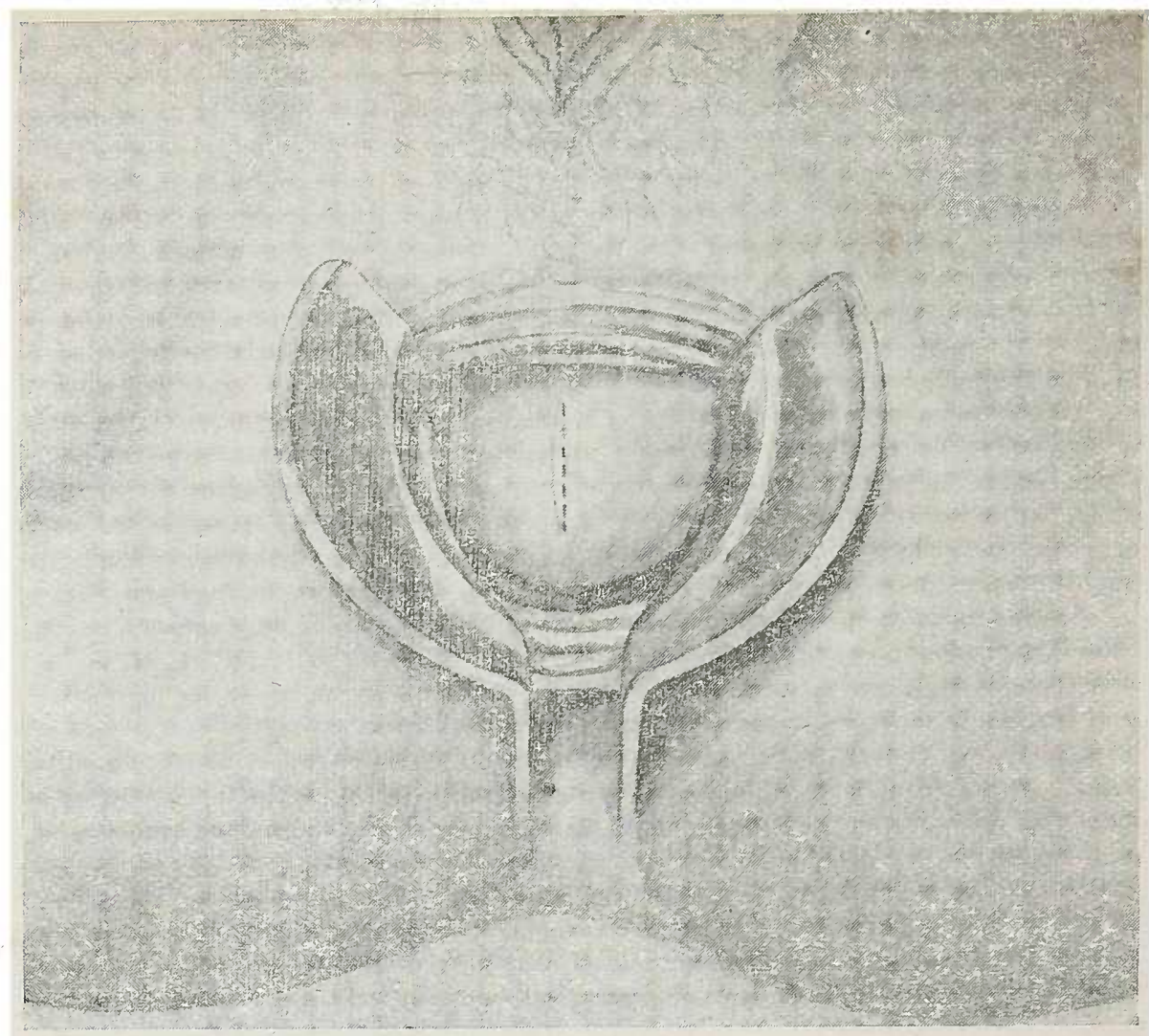

FIG. 3

Apús a dilatação do anus, observa-se o abaulamento da parede anterior do réto. A linha pontilhada inর্cica a direção da incisāo.

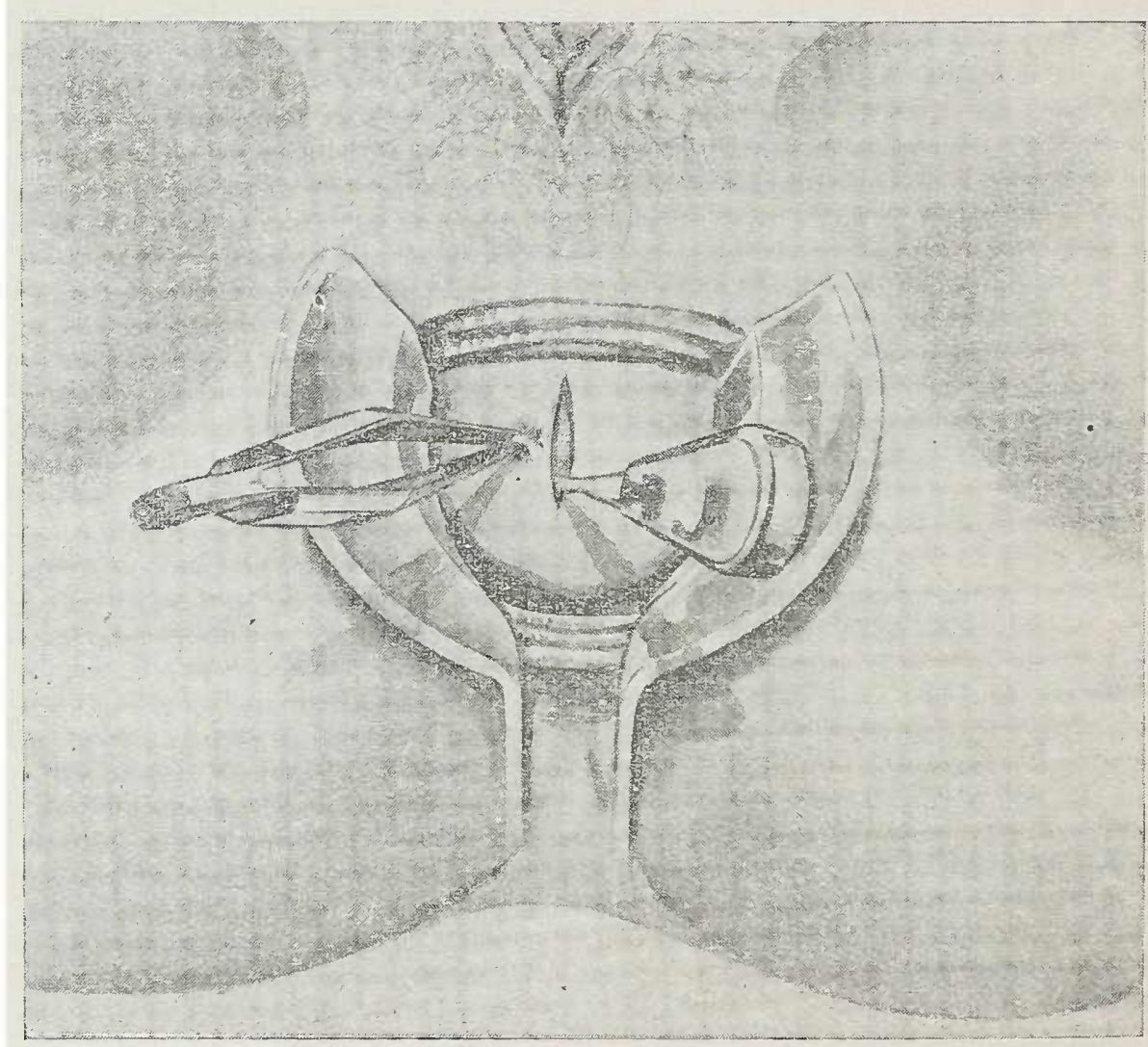

FIG. 4

Fixando-se a thucosa retal com uma pinça longá, faz-se a sua incisão no sentido longitudinal com bisturi. Abaixo da mucósa nota-se a carhada muscular. 


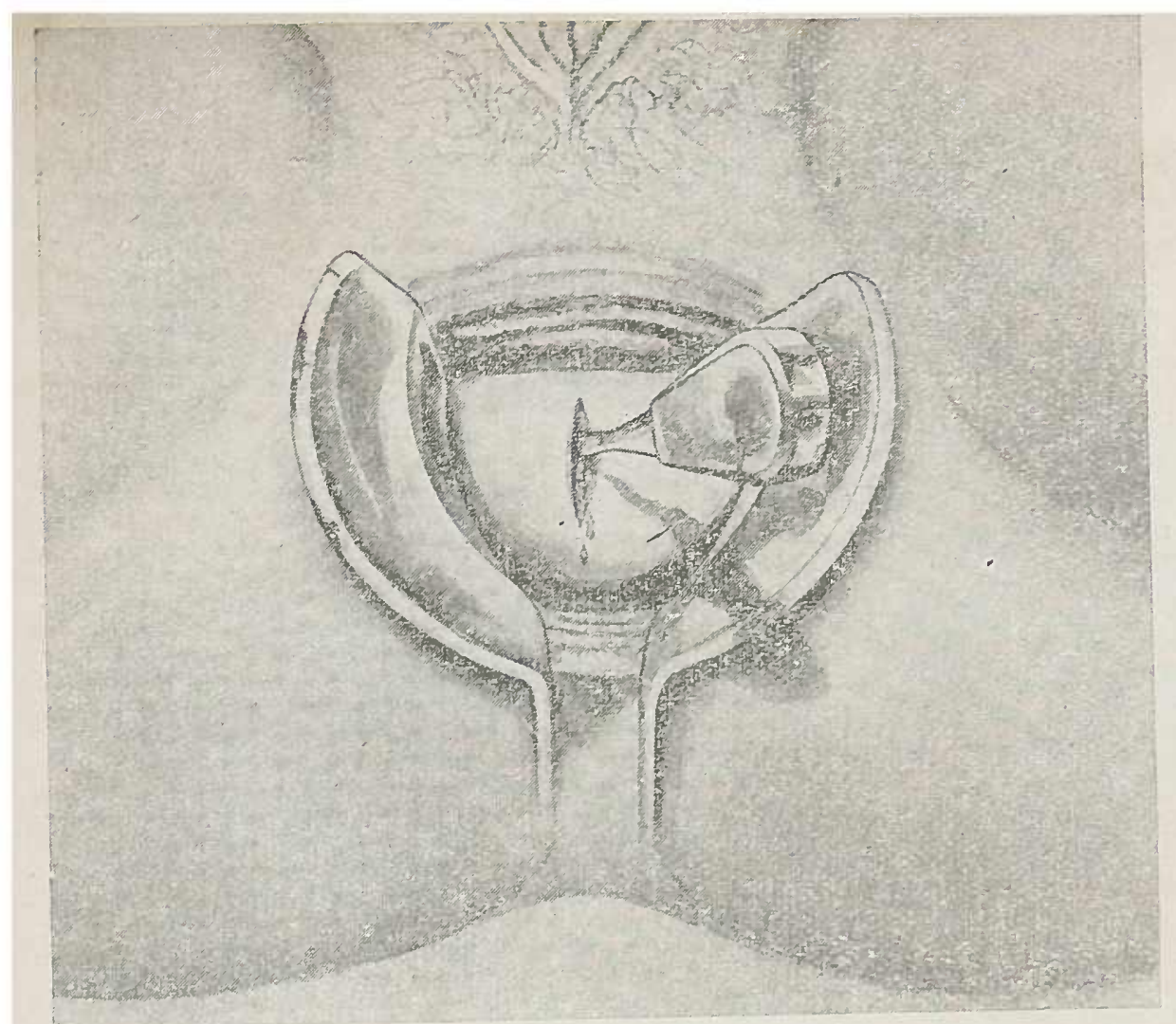

FIG. 5

Secionada a mucósa, faz-se a perfuração da muscular com o bisturi. Dessa maneira evitam-se os falsos caminhos.

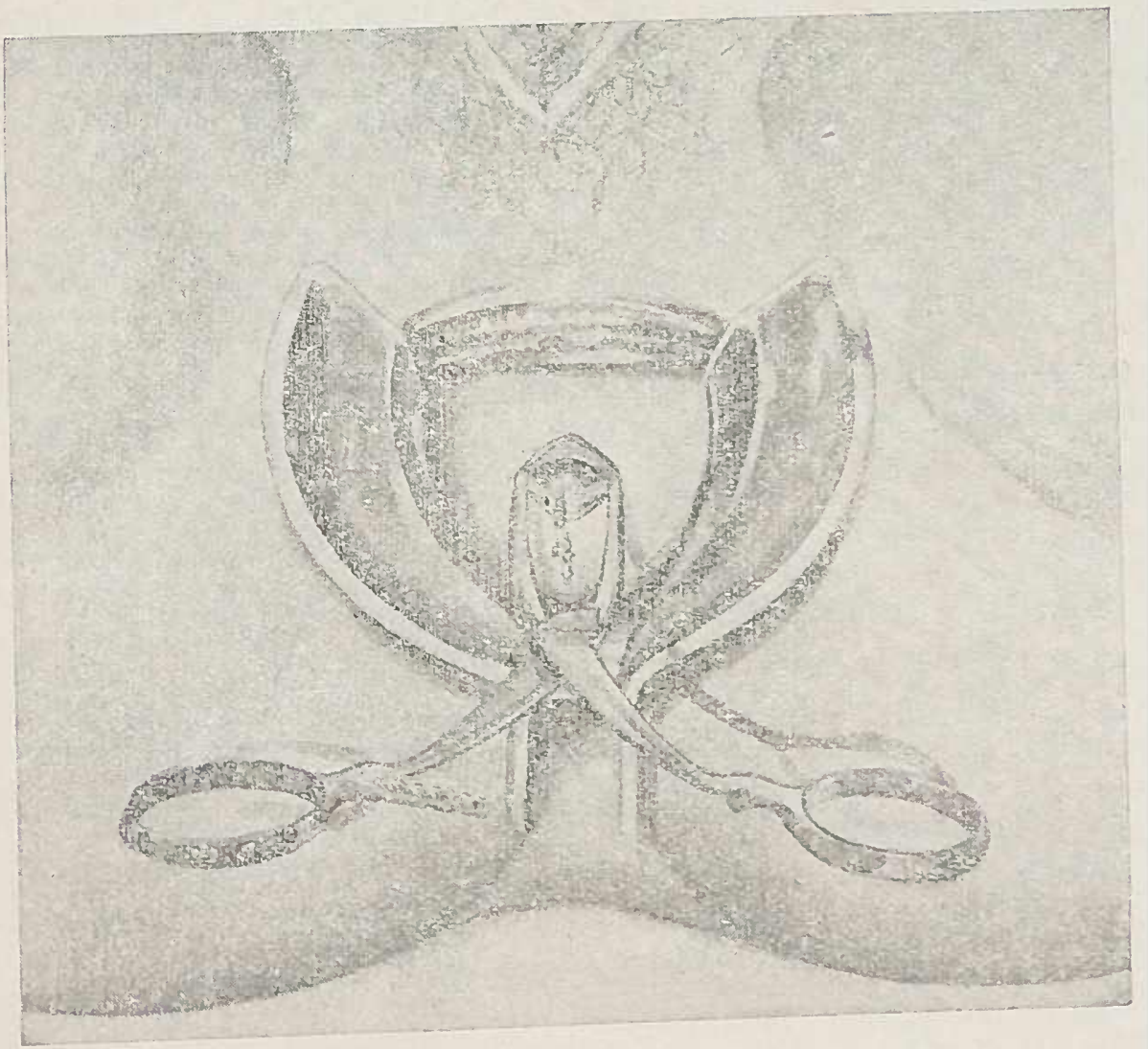

FIG. 6

Após a abertura do abcesso, faz-se a dilatação do orificio praticado. e por ai introduz-se um dreno de borracha. 


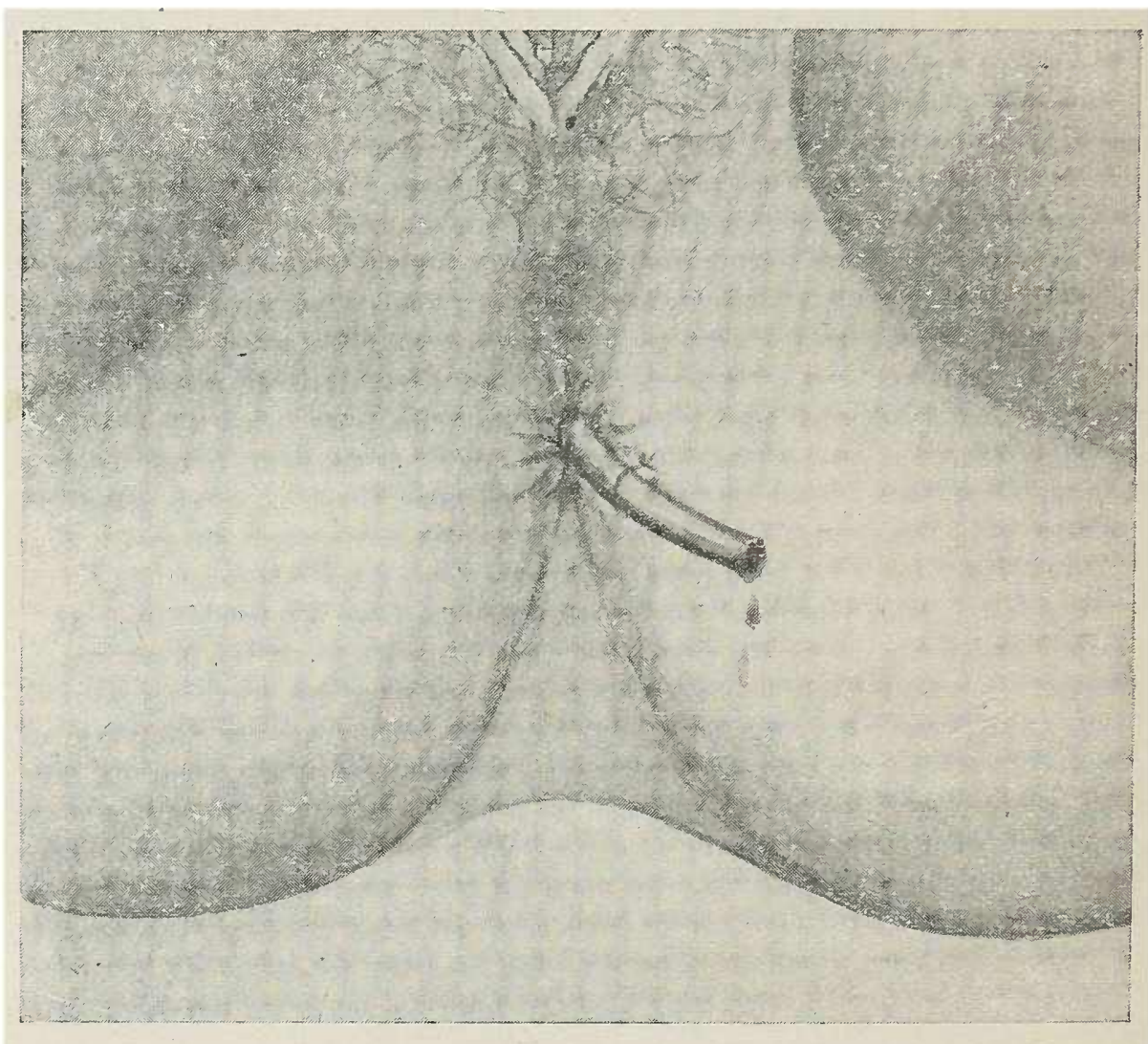

FIG. 7

O dreno deve ser suturado á pele que circunda o anus, para evitar que seja eliminado durante as evacuações. 


\section{RESULTADOS}

PETITCLERC teve a oportunidade de abrir, durante 20 arrs, 42 abcessos do Douglas pela prototomia. Nenhum caso faleceu, apesar da existencia de outras lesões graves no apendice. Em 4 vezes foi obrigado a operar mais de uma vez o mesmo paciente por se tratar de abcessos com multiplas lojas.

STUDEMEISTER estudou 883 apendicectomias sendo $803 \mathrm{em}$ crise aguda e 80 em estado crônico. Nesses casos 11 vezes observou perturbações no Douglas sendo que 5 casos curaram com tratamento conservador; em todos eles sómente havia serosidade ou infiltrado. Nos 6 casos restantes havia pús franco no Douglas; todos os casos tinham sido operados em fase aguda de apendicite; foram todos drenados por via retal com sucesso. Esses 6 casos fazem $0,7 \%$ de todos os casos de apendicite estudados.

No Serviço do professor Alipio Correia Neto reunimos um material de 284 casos de apendicite, dos quais 279 foram operados, sendo $64 \mathrm{em}$ fase aguda (apendicite aguda, apendicite aguda supurada, apendicite aguda perfurada ou apendicite aguda gangrenada) e 215 em fase crônica.

Entre as 279 apendicictomias praticadas, apenas 4 pacientes apresentaram processos patológicos do Douglas. 2 desses pacientes (obs. 1 e 2) tinham sido operados por uma apendicite supurada e tive:am posteriormente abcesso do Douglas, que só se curou com drenagem. Os outros 2 pacientes (obs. 6 e 7 ) tinham sido operados por uma apendicite em fase crônica; um deles chegou a apresentar pús no Douglas e o outro somente exsudato, mas ambos curaram-se com o tratamentc conservadôr.

A éssas 4 observações reunimos mais duas, de pacientes da cítnica particular do prof. Alipio Correia Neto (obs. 4 e 5 ), em que os pacientes foram operados na fase dita clinicamente subaguda, ou seja, em fase de "esfriamento" de um processo agudo. Outra observação (n. ${ }^{\circ} 3$ ), foi-nos gentilmente cedida pelo Dr. Luiz Iervolinn e trata-se de um abcesso do Douglas após uma apendicite supurada, que se abriu expontaneamente na bexiga.

\section{OBSERVAÇÕES}

Obs. n. 1: V. Z., 28 anos, branco, operario.

O paciente sentiv ligeira dôr no abdomen á tarde, após o jantar, vomitando o alimento ingerido. Passou bem á noite, mas ao levantar-se sentiu uma dôr forte, como uma facada na fossa iliaca direita; não conseguiu locomover-se; teve nauseas e vômitos. Ingressou no serviço pela manhã, apresentando aspecto de intoxicação geral e permanecendo sempre sentado com o fim de acalmar suas dores. Apresentava hiperestesia cutanea na fossa iliaca direita, defesa em todo abdomen, mais acentuada na fossa iliaca direita. Pelo tóque retal, provoca-se dôr no fundo de saco de Douglas.

Foi operado, encontrando-se na fossa iliaca direita um liquido purulento. Após uma ligeira pesquisa, foi encontrado o apendice que apre- 
sentava uma perfuração por onde havia saída de fézes. Apesar disso o peritonio não foi drenado.

O paciente continuou 'com elevações vespertinas da temperatura até $38^{\circ}$; no $5 .^{\circ}$ dia abriu-se a incisão na fossa iliaca direita com grande supuração. Continuou a fébre e apareceu ileo paralítico, seguido de diarréia. No $9 .^{\circ}$ dia o tóque retal revelava um abaulamento na parede anterior do reto. Defesa na parte inferior do abdomen. Além do tratamento geral foram feitos clisteres com líquido quente. No dia seguinte uma punção do Douglas revelou pús, e o abcesso foi aberto saindo 400 c.c. de pús espesso e fétido. A temperatura caiu imediatamente e os outros sintomas desapareceram. O Douglas não foi drenado e no dia subsequente, havia nova coleção. Com auxilio de uma pinça de Kocher foi reaberta a incisão dando saída a cerca de 200 c.c. de pús. Nos 2 dias segúintes o paciente eliminava pequena quantidade de pús nas fezes. No $30^{\circ}$ dia após a operação, o tóque retal nada revelava de anormal, sendo ligeiramente doloroso. O paciente teve alta curado.

Obs. n. ${ }^{\circ}$ : J. de Deus, 14 anos, branco, operario.

A anamnése revela dôr forte em todo abdomen, aparecendo gradativa. mente após uma refeição. Teve nauseas e vômitos. Algumas horas depois, a dôr localizou-se na fossa iliaca direita que se apresentava mais rígida que o resto do abdomen; havia hiperestesia cutanea, temperatura $37^{\circ}, 6$ e pulso 106. Foi operado 76 horas após o inicio da crise e apresenrava um apêndice retro-cecal perfurado e na fossa iliaca direita havia grande quantidade de pús (cerca de 200 c.c.). Foi feita a drenagem tubular da fossa iliaca. Nos dois primeiros dias o paciente continuou com hipertermia vespertina até $38^{\circ}, 2$; dores na fossa iliaca direita. No $3 .^{\circ}$ dia teve diarréia, mas nos dois dias seguintes passou bem. No $70^{\circ}$ dia teve cólicas abdominais, dôres no abdomen inferior e diarréia acompanhada de muco. $\mathrm{Na}$ fossa iliaca esquerda a palpação profunda tambem desperta dôr; a temperatura é de $38^{\circ}, 4$. No $10^{\circ}$ dia do posoperatório a diarréia persistia com muco nas fézes, dôres abdominais e o toque retal revelou um abaulamento da parede anterior do réto na altura do Douglas. No dia seguinte, sob anestesia geral, pratica-se a punção e abertura do abcesso, dando saída a 150 c.c. de pús amarelo, esverdeado e fétido; faz-se a drenagem tubular. No dia seguinte o dreno foi eliminado $\mathrm{c} \cap \mathrm{m}$ as fézes e a incisão da parede retal foi dilatada com uma pinça de Kocher, dando saída a grande quantidade de pús. $O$ estado geral do doente melhorou e continuou por mais 3 dias a eliminar pequena quantidade de pús de mistura com as fézes. Diariamente fazia-se um tóque retal dilatando-se com o dedo o orificio da parede do réto. O estado geral melhorou muito e o paciente permaneceu na enfermaria em tratamento por mais alguns dias, pois a primeira incisão cirúrgica tambem supurava muito com aspecto e odor de fistula estercoral.

O paciente recebeu alta curado, 37 dias após a operação.

Obs. n. ${ }^{\circ}$ 3: D. G., de 75 anos de idade.

Trata-se de uma senhora que ha 48 horas apresentava dores contínuas em todo abdomen, sendo que na fossa iliaca direita as dores apresentavam maior intensidade. Tinha defesa muscular generalisada em todo o abdomen e hiperestesia cutanea na fossa iliaca direita.

Foi operada de urgencia, encontrando-se um apêndice gangrenado e grande quantidade de pús na cavidade peritonial. Nos primeiros 4 dias que se seguiram á operação houve hipertermia que não cedeu ao cloreto de sódio hipertônico feito en grande quantidade. Então, no $5 .^{\circ}$ dia a paciente apresentou diarréia intensa com catarro; a temperatura continuava elevada. Um tóque retal mostrou um abaulamento no Douglas. 'Foi instituido um tratamento conservador com clisteres quentes, com o que as dôres diminuiram. Dois dias depois inesperadamente a paciente começou a urinar grande quantidade de pús e a temperatura caiu imediata- 
mente; melhorando dos outros sintomas. A piuria durou 3 dias, durante os quais foram ministrados antiséticos urinarios. A doente entrou em convalescença, tendo alta curada.

Estas 3 observações são muito demonstrativas. Em todas elas trata-se de uma apendicite aguda acompanhada de peritonite; no primeiro caso havia perfuração do apêndice. Evidentemente a infecção do Douglas originou-se pelo pús drenado da região apendicular. Houve um excesso de confiança na força de resistencia do peritonio contra a infecção, pois a existencia de pús franco e particularmente de fézes tornam a drenagem obrigatória; entretanto não se póde afirmar que a drenagem teria evitado o abcesso do Douglas. A história clínica de todos os casos é típica. O terceiro caso é particularmente interessante por ter havido uma abertura espontanea do abcesso na bexiga, por perfuração de sua parede posterior. Mesmo assim a doente curou-se, sem haver uma fistula ou infecção urinaria crônica.

As observações seguintes são de abcessos do Douglas aparecidos após apendicectomia no periodo de cura de uma fase aguda (chamada clinicamente de subaguda).

Obs. n. 4: R. C. M., 33 anos, advogado.

$O$ paciente queixa-se de dôres localisadas na fossa iliaca direita com irradiações para a região lombar direita. Essas dores são fracas, continuas e aparecem com intervalos variaveis, de 4 mezes para cá. 15 dias antes da operação teve uma crise pouco mais forte. Daí para cá continúa a sentir dores na fossa iliaca e prisão de vente.

A palpação da fossa iliaca revelava a existencia de 2 cordóes duros, não gargarejantes e dolorosos. Foi feito o diagnóstico de apendicite subaguda e o doente foi operado pelo prof. Alipio Correia Neto. De fato. o apêndice estava em posição iliaca baixa, apresentava a parede espenta do côto apendicular.

O paciente passou bem durante 4 dias, tendo-se transferido para sua residencia com alta. No $5^{\circ}$ dia teve dôres em forma de cólica no baixo ventre, fébre e diarréia. No dia seguinte o tóque retal revelou a existencia de abaulamento no réto e foi feito o diagnóstico de abcesso do Douglas. Uma punção revelou um líquido sanguineo-purulento e foi feita $\mathrm{O}$ abcesso do abcesso, dando saída a cerca de 300 c.c. No No $30^{\circ}$ dia, como o dreno tifoi drenado. A sintomatologia desapareceão digital da incisão sol) anestevesse sido eliminado, procedeu-se a dilataça paciente teve alta curado. sia geral. Algum líquido foi eliminado.

Obs. n..$^{\circ}$ 6: D. C., 19 anos, operario.

$\mathrm{Ha} 15$ dias atraz teve dôt de forte intensidade, localisada na fossa iliaca direita. Teve nauseas, mas não vomitou. Na ocasião teve hiperteiliaca direita. Teve nauseas, mas náo vomisa prisão de ventre e ligeira
mia. Após 2 dias estava bom, mas conservava pris revelava a existencia
dôr na fossa iliaca direita. A palpacão do abdomen rendo que a dôr prode 2 cordões finos na fossa iliaca direita, dolorosos, sendo que a dor pro- 
vocada irradiava-se para o epigastrio. Com o diagnóstico clínico de apendicite sub-aguda o paciente foi operado pelo prof. Alipio Correia Neto. Encontrou-se um apendice enorme, do tipo infantil, retrocecal, em parte intraperitonial e em parte extraperitonial. Foi feita a apendicectomia, não se fazendo sepultamento do côto apendicular. O meso apendice foi ligado 2 vezes.

Passou bem até o $4 .^{\circ}$ dia, quando teve alta. Ao chegar em sua residencia teve fortes dores em todo o baixo ventre e especialmente na fossa iliaca esquerda. Ao mesmo tempo teve diarréia $\operatorname{com}$ fezes liquidas e acompanhadas de sangue; teve tambem tenesmo. Um exame das fezes não revelou nenhum parasita. Apresentava T. $38^{\circ}$. Foi novamente removido para o Hospital, onde um tóque retal revelou, um tumor no fundo de saco de Douglas. Esse tumor foi puncionado, encontrando-se um líquido sanguineo-purulento. Foi feita a abertura cirúrgica da coleção, com drenagem tubular. Ao cabo de 2 dias não apresentava mais nada e o dreno foi retirado. O paciente recébeu alta curado.

Estas duas observações são tambem muito interessantes pois os pacientes foram operados durante a fase de cura de um processo agudo. O peritonio estava em ótimas condições e não havia absolutamente pús, nem exsudato peritonial. A operação foi corréta e em um dos casos o méso foi ligado 2 vezes por precaução. Mesmo assim formou-se o abcesso do Douglas.

As duas observações seguintes são de apendicites operadas em fase crônica.

$$
* * *
$$

Obs. n.* 6: W. C., 17 anos, branco, operario.

Ha 5 mezes o paciente começou a ser incomodado por dôr localisada na fossa iliaca direita, que cedeu espontaneamente. Passou bem até alguns dias antes de internar-se, quando teve novamente as mesmas dores, nauseas e sensação de repuxamento na face antero-interna da coxa direita. Ao exame físico apresentava dôr á palpação da fossa iliaca direita, mais acentuada quando se palpava com o musculo psoas em contração. Foi operado com o diagnóstico de apendicite crônica, sob anestesia peridural, encontrando-se o apendice em posição iliaca média e sem sinal nenhum de processo inflamatorio agudo; fez-se a apendicectomia. O exame anatomopatológico revelou apendicite crônica.

No posoperatório teve temperatura ascendente até o $3 .^{\circ}$ dia, pelo que foi responsabilisada uma ligeira bronquite. Nesse dia teve evacuações disenteriformes, T. $39^{\circ} \mathrm{C}$, pulso 114 , dôres no abdomen inferior; um toque retal mostrou um empastamento logo acima da prostata, muito doloroso. Passou na mesma mais dois dias, ao cabo dos quais fez-se novo tóque retal, que mostrava um abaulamento da parede anterior da ampola retal. Foi feita uma punção que deu pús esverdeado; foi feito o esvasiamento do abcesso pela aspiração, e instituido tratamento conservador por clisteres aquecidos. Melhorou a disenteria, as dôres abdominais, mas a temperatura permanecia elevada. Um exame dos pulmões mostrou atelectasia da base esquerda, que foi tratada pelo $\mathrm{CO}^{2}$, decubito direito e tussigenos. O processo do Douglas involuiu completamente e o paciente teve alta curado.

Obs. n. ${ }^{\circ}$ 7: J. P. C., 16 anos, pardo, copeiro.

De 2 mezes para cá o paciente é incomodado por dôres localisadas na fossa iliaca direita, continuas e de pequena intensidade; ha 15 dias tem tambem prisão de ventre. De nada mais se queixa e os antecedentes não interessam. O exame físico revela de anormal dôr na fossa iliaca direita 
durante a palpação de 2 cordões não gargarejantes e duros; com o psoas em contração a palpação é mais dolorosa. Foi operado com o diagnóstico de apendicite crônica e sob anestesia péridural. $O$ apendice estava em posição latero-cecal interna, livre e não havia sinais de inflamação aguda; fez-se apendicectomia sem sepultamento do côto apendicular.

Desde o $20^{\circ}$ dia do pósoperatoria o paciente apresentou dôr em forma de cólica no baixo-ventre, temperatura $39^{\circ}$ e constipação; o tóque retal era doloroso, mas não havia empastamento supraprostático. Passou na

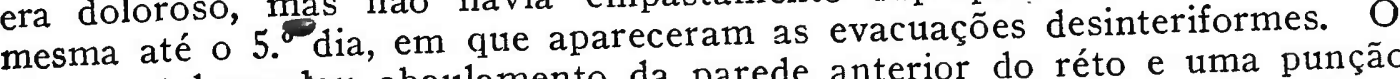
tóque retal revelou abaulamento da parede anterior do réto e uma punção deu saída a um exsudato, cujo exame direto foi negativo; com a cultura houve crescimento de germens do grupo coli. Foi instituido o tratamento conservador com clisteres aquecidos e cloreto de sódio em solução hipertónica na veia, e o paciente melhorou progressivamente. 4 dias depois 0 tóque era indolor $\mathrm{e}$ as evacuações haviam-se normalisado. Teve alta curado 5 dias após.

Estas observações são interessantes porque o processo do Douglas apareceu sem haver inflamação aguda intraperitonial e tambem porque houve cura pelo tratamento conservador.

\section{RESUMO}

$O$ autor faz um estudo de conjunto sobre os exsudatos e abcessos do fundo de saco de Douglas após as apendicectomias. Distingue os casos aparecidos após as apendicites supuradas e crônicas; entre. os primeiros lembra que o pús da fossa iliaca direita drena para a pequena bacia; para o segundo grupo dá importancia á hemorragia intraperitonial na patogenia do abcesso. Na sintomatologia chama atenção para as evacuações disenteriformes e relaxamento dos esfinteres do anus, descrevendo a sua fisiopatogenia. Lembra a possibilidade da abertura em orgãos visinhos como a bexiga e a cavidacle peritonial livre e para evitar essas graves complicações propõe que se faça a abertura cirúrgica pelo réto, desde que o abcesso esteja completamente formado. Refuta as objeções feitas á via retal pelos autores que preferem a via suprapúbica. Descreve 7 casos, sendo 3 após apendicites agudas supuradas, 2 após apendicites agudas no periodo de cura, e 2 após apendicités crônicas.

\section{SUMMARY}

The author studies the exsudats and abcess of the cul sac of Douglas after the appendicectomies.

He separates the cases following the suppurative and the cronic appendicitis: the former are done by the drainage of pus from the right iliac region to the cul of sac. In the cronic cases he gives importance to the intraperitoneal hemorrhage in the pathogeny of the abcess.

In the symptomatology he calls attention to the disenterylike evacuations and relaxation of the anus sphincteres and describes its 
physiopathogeny. He points out the possibility of an opening in the surrounding organs like the bladder and the peritoneal cavity and to avoid these grave complications he proposes that a surgical opening be made through the retum, as long as the abcess be completely formed.

He refutes the objections made to the retal way by the authors who prefer the supra-pubic incisions.

He describes 7 cases: 3 after supp. acute appendicitis; 2 after acute appendicitis e 2 after appendicectomie for cronic cases.

\section{ZUSAMMENSFASSUNG}

Der Verfasser stellt eine zusammenfassende Untersuchung über die Exsudate und Abcesse der Tiefe des Douglasschen Sackes nach Apendektomie an. Er unterscheidet $z$ wienschen den nach eiteriger und nach chronischer Blinddarmentzündung zur Erscheinung gekommenen Fällen; was die ersteren anbetrifft, so erinnert er daran, dass der Eiter der rechten Fossa iliaca nach dem kleinen Becken abläuft; hinsichtlich der zweiten Gruppe misst er der intraperitonealen Hämorrhagie besondere Bedeutung für die Pathogenese des Abscesses zu. Was die Symptomatologie anbetrifft, so macht er auf die dysenterieähnlichen Entleerungen und die Erschlaffung der Sphinkter des Anus aufmerksam, wobei er deren Physiopathologie beschreibt. Er erinnert an die Möglichkeit der Eröffnung in benachbarte Organe wie die Blase und die freie peritoneale Höhle; um diese schweren Kompliationen zu vermeiden, schlägt er vor, die chirurgische öffnung durch das Rectum vorzunehmen, sobald der Abscess völlig ausgebildet ist. Er weist die Einwände zurück, welche von den Autoren, die suprabubische Ôffnung vorziehen, gegen den rectalen Weg erhoben wurden. Er beschreibt 7 Fälle von Blinddarmentzündungen, nänlich 3 nach geeiterter, akuter Entzündung, 2 andere nach akuter zur Zeit ihrer Heilung, und schliesslich 2 weitere nach chronischer Appendicitis.

\section{BIBLIOGRAFIA}

BAILEY, HAMILTON - A note on drainage of a pelvic abscess per rectum, and the indications for the selection of this route. Lancet, 213: 754-755, obt. (8) 1927.

CHUTRO, PEDRO - Complicationes post-operatorias de la apendicitis. Congresso Arg. Cir., 2. ${ }^{\circ}$ : 223-335, julio 1930. CONDAMIN, M. - Douglassite e apendicectomie. Lyon Chir., 24: 88-96,

COULSON, T. E. - Drainage of pelvic abcess in acute appendicitis. Brit. M. J., 2: 789, oct. (15) 1938.

DIEZ, B. RIVAS - La celulitis retroperitoneal post-apendicular. Semana Med., 45: 515-519, set. (1) 1938.

ESAU, PAUL - Dié Erschlaffung des Sphincter ani beim Douglas53: 981-984, april (17) 1926. 
FAGERSTROM, DUDLEY P. - Perforation of the urinary bladder by pelvic abcess. With a report of two cases. J. Urol., 30: 201-220, august 1933.

FREIBERG, JOSEPH and PERLMAN, ROBERT - Pelvic abscesses associated with acute purulent infection of the hip-joint. J. Bone and Joint Surg., 18: 417-427, abril 1936.

GRASMANN, MAX - Die Dolglasuntersuchung. Münch. Med. Wschr., 79: 630-632, april (15) 1932.

HERTZLER, ARTHUR E. - Surgical Pathology of the peritoneum. Lippincott Company, Philadelphia, 1935.

KEYES, E. LAWRENCE - Death from appendicitis. The mortality from appendicitis and the causes of death following appendicitis. Ann. Surg., 99: 47-68, jan. 1934.

KLEINBERG, SAMUEL - Pelvic abcess in the male. Arch. Surg. 14: 1267-1270, june 1927.

KRECKE, A. - Die Untersuchung des Mastdarms in der Praxis. Münch. Med. Wschr., 78: 1003-1006, juni (12) 131.

LAWEN, A. - Über Erschlaffung des Sphincter ani beim-Douglasabszess. Münch. Med. Wschr., 68: 1484-1485, nov. (18) 1921.

LEHMAN, EDWIN and PARKER, WILLIAM - The treatment of intraperitonial abcess arising from appendicitis. Ann. Surg., 108: 833-856, nov. 1938. 833-856, nov. 1938.
MC GREGOR, A. LEE - Gravity drainage of pelvic abcess. Brit. J.
Surg., 24: 292-296, oct. 1936.

MEYER, HAROLD - The reaction of the retroperitoneal tissues to infection. Ann. Surg., 99: 246-250, feb. 1934 .

PAVLOVSKY, ALEJANDRO - Complicaciones

CLERC, J. L. - Proctotomie dans quarænte-deux cas d'appendicite suppurée. Laval Med., 1: 61-63, abril 1936.

RANDON, F. T. - Pelvic abcess caused by bacterium typhosum. Lancet, 220: $1398-1399$, june (27) 1931 .

RITCHIE, HARRY P. - Rectal section to 1918 . $124-428$, august (10) 190 . Douglas-Abcess. Der ChiSTUDEMEISTER, A. - Der appendicitische Do rurg., 8: 727-732, set. (15) 1936 .

VAUGHAN, ROGER T. - Appendicitis. Nelson Surgery, 5. 297-342. 